\title{
Action-Structure Paradox in a Strategic Information System Change Process
}

\author{
Taru Salmimaa \\ Tampere University of Technology \\ taru.salmimaa@gmail.com
}

\begin{abstract}
Any strategic Information System (IS) change process is at risk of a failure because of its inability to evolve as rapidly as the business environment. In this Grounded Theory study, aspects of socio-cognitive inertia arose in a 15-year customer-vendor relationship involving excessive optimism and trust in decisionmaking about technological options, knowledge sharing, and development practices. The pre-existing collaboration model was ultimately not supportive of the targeted strategic IS change. As a result, pressures to change the mode of operating emerged at the critical phase of initial rollout. This paper contributes to the IS change literature by presenting and theorizing an action-structure paradox identified during this study of strategic IS change.
\end{abstract}

\section{Introduction}

Strategic Information System (IS) change processes aim to enable both strategic and operational competitive advantages to implementing organizations through a contextually appropriate use of technologies and design practices aligned with key business development imperatives [1,2]. As is all too often apparent, these multi-faceted strategic IS change processes involve high levels of uncertainty, both relating to the operating environment, but also because of their reliance on a set of contingent inter-organizational activities such as strategic goal setting, requirements management, coordination of interrelated tasks across the organizational boundaries, use of novel technologies and management business partnerships $[3,4]$.

As reducing or eliminating uncertainties in a volatile business environment is often impossible, it is important to instead learn how to proactively cope with uncertainties [5]. This includes an acceptance of tensions arisen in strategic decision-making because of diverging strategies (e.g. exploring-exploiting, aligningadapting), where both alternatives nevertheless have to be taken account for an achievement of long-term business benefits [6]. Through contradictions and opposing views it is also possible to facilitate fresh ideas and new perspectives among stakeholders which are often necessary for innovative solutions and change [7].

This paper presents the results of theoretical coding (TC) and development of the higher-level theme, the dynamic forming of social occurrences and paradoxes in a strategic IS change, with the classic GT methodology $[8,9]$ conducted in a business critical IS change case. The aim of study was to increase an understanding of specific behavioral models and interactions of actors by examining strategic IS change in a trust-based and long IS partnership between the customer and vendor.

The customer and vendor developed the new IS product for their future business model changes. The customer aimed to achieve the competitive advantage with the customized IS features in their global retail business with 180 user organizations. As for, the vendor aimed at a scalable customer base with the new technical platform on which it would be easy to configure the customer-specific requirements. Both participant organizations had optimistic expectations for an outcome of the strategic IS change process.

The research question to this paper is: What kinds of tensions and uncertainties arise in social interactions and how these effect on the dynamics of strategic IS change? The data is collected by interviewing the 16 actors in key roles across the strategic IS change organization. Through the open and selective coding phases, 15 selective codes were discovered in two core categories: 1) 'Management of Change'; and 2) 'Tension and Uncertainty'.

The first core category ('Management of Change') includes seven change management activities identified through the selective coding phase: 1.1) Clarifying the goals; 1.2) Maintaining the overall view; 1.3) Making sense of the IS model; 1.4) Making the evolving processes visible; 1.5) Coping with the change; 1.6) Being aware of the informality; and 1.7) Enhancing the collaboration.

The contextual conditions, which were described as sources of tensions and uncertainties, were also discovered in the selective coding phase, and formed the second core category ('Tension and Uncertainty'): 2.1) Leading the way; 2.2) Expectation; 2.3) Decision making; 2.4) Excessive optimism; 2.5) Dynamic nature; 
2.6) Inconsistency between knowledge and business view; 2.7) Instability; and 2.8) Tensions in collaboration. Some contextual conditions were sensitive to the history of the case. For example, the trust-based IS partnership, the optimistic atmosphere, the selection of novel technologies, the IT-driven development model, and the distributed organizational structure were already present when the strategic IS change process was started.

Seven social occurrences are examples of social structures formed in an integration of two core categories 'Management of Change' and 'Tension and Uncertainty' with 15 selective codes. In practice, relationships between the selective codes are justified with the aid of abstract "theoretical codes" (social occurrences, see Table 3). In these social occurrences, different kinds of actions were conducted for advancing the strategic IS change process. Added to that it was discovered, in the trust-based IS partnership, the actors had more freedom to choose what kinds of artefacts, means, or social arrangements were used in actions. Variations enabled by individual level acting increased contingencies to social occurrences and strategic IS change process. In this vein, the strategic IS change process studied can be explained as an emergent initiative with both intended and unintended consequences of actions [10].

Based on the implications drawn from the GT theorizing phase, in which the literature is reviewed aligned with the analysis, the relationship between the organizational structure (social occurrence here) and situated action is considered as 'dualistic'. Different choices in actions at the different organizational levels with the specific timing (when the action is done, such as at the early phase or at the phase of initial rollouts) have effect on the consequences of actions, and in this way to the co-evolvement of change management activities in a social occurrence.

The decisions made during the strategic IS change were also influenced by the socio-cognitive aspects and prevailing organizational culture. For example, an excessive trust on an individual level acting, in which one IT manager was responsible for the overall view of the strategic IS change, decreased the participation of the other actors to the critical decisions in the new IS product development.

Cameron and Quinn [14, p. 25-35] in their book 'Paradox and Transformation' highlight tensions between the social structures (more collectiveorientation, macro-level, an organization) and actions (more self-orientation, micro-level, an individual) because an action and a social system with structural properties are inseparable, but also contradictory in relation to each other. In this study, the action-structure paradox is proposed as a theoretical perspective for explaining the dynamics of social occurrences through the situated actions in which the individual actors are purposeful. In the trust-based IS partnership, individuals and groups (in micro-level actions) can drive for their own desires and motives to the change management activities although the strategic IS change organization (in macro-level management structures) has the specific change strategy. Hence, it has been assumed that the choices of individuals and groups are also bounded by organizational structures and prevailing atmosphere in a strategic IS change process which include the shared beliefs and values above the groups [15].

When comes to the dynamic behaviors of social occurrences in a context because of a set of choices in actions and contextual conditions, the forming of both virtuous and vicious cycles of change can be observed being as a part of strategic IS change initiative [16,17]. Based on the earlier paradox studies [18-20] vicious cycles of change can feed an organizational inertia what is defined "inabilities for organizations to change as rapidly as the environment" [21, p. 163]. For example, in this case, a critical misalignment challenge emerged between the macro (the management steering group) and micro (the IS product development) views after the leaving of critical boundary spanner role.

Main contribution of the study is to introduce two propositions emerged in the TC phase of GT study:

A) There are dynamic behaviors of change management activities in forming of new social occurrences in a context; and

B) The paradoxical situations emerge because of a set of choices in actions are not aligned with the aims in the strategic IS change.

These propositions aim at bring a new knowledge in the field of strategic IS change literature [22]. In the contribution of this paper, the sources of tensions and uncertainties in a strategic IS change are analyzed. This also includes socio-cognitive inertia aspects facilitated by the long and trust-based IS partnership [13]. Moreover, the situated-based nature of socio-technical system [23] is explained by the co-evolvements of change management activities in social occurrences.

The paper is structured in follow. The next chapter summarizes the theoretical background. The third chapter recaps the methodological aspects and research settings. The fourth chapter describes the case. The fifth section shows the results of TC with the implications of the findings in relation to the literature. The sixth chapter concludes with a brief summary of the contribution and future prospects with the interesting research avenues. 


\section{Theoretical background}

After the discovery of two propositions in GT process, and a construction of higher-level theme, the theoretical assumptions from the paradox and ambidexterity literature were reviewed $[6,14,18,24,25]$. This is a part of theoretical integration phase in the GT process in which the own substantive theory is viewed through the existing theoretical assumptions [26,27]. Following sections describe the relevant concepts from the existing literature to this paper.

\subsection{Paradox and Ambidexterity Thinking}

As concluded in the recent IS research journal by Gregory et al. [28], the paradox and ambidexterity are related concept although these primarily have a different meaning - a paradox means "denotes contradictory yet interrelated elements - elements seem logical in isolation but absurd and irrational when appearing simultaneously " [24, p. 760], and an ambidexterity means "ability to simultaneously pursue" both poles in the opposing demands [29, p. 18] such as an aim to achieve both incremental and discontinuous innovation streams simultaneously [30].

In general, the purpose of 'ambidexterity' thinking is an organizational capability to cope with the change and paradoxes within it [31]. It is commonly used in the management research in leadership, organizational adaptation, design and learning, strategic management, and technological innovation [32-37]. Moreover, the difference between the concept of ambidexterity and "resolutions to paradoxes" is understood by reviewing the work of Jarzabkowski et al. [38] in which resolutions to paradoxes are typed at the detailed level, and are more specific to the strategic management. Poole and Van de Ven [25] have proposed two approaches for coping with the paradoxical situations: 1) by accepting the paradox (i.e. keeping tensions separate and appreciating their differences), or 2) by finding a resolution to the paradox (i.e. spatial or temporal separation, or synthesis). For example, the different types doings in an IS product development can be separated to the different units for managing the exploring and exploiting simultaneously, and building the contextual ambidexterity with the appropriate adaptation and alignment acts [39]. Paradoxical situations may arise just because of pressures to create new socio-technical structures throughout the process in which many activities are dependent on the situated actions with design artefacts and tools used in a context [23].

In the strategic IS change, it can be challenging to operationalize the multi-faceted alignment activities to micro-level practices, especially, when the IS strategy evolves aligned with the changing business needs [40]. Sometimes temporary misalignments during a strategic IS change, often seen as vicious cycles in a sociotechnical system, can be recovered with the right kinds of strategic acts like changing the decision-making structures (centralized vs. distributed) [41].

\subsection{Action-Structure Paradox in Interpretative Process Theory}

Sociologists have been interested in the theory of action-structure paradox because it provides the point of view to explain the role of individuals as a part of society by focusing on both aspects (a part-whole relationship) [42]. Through the years, ambiguities in the interpretations of the relationship between an action and structure have evolved because the researchers have different ontological and epistemological assumptions for action-structure paradox [14, p. 27]. For example, an ontological essence of structure is seen as tangible whereas an action is often dependent on motives of individual actors, and is seen intangible. In this interpretative strategic IS change study, the actionstructure paradox has been considered for explaining the behaviors of social occurrences through the situated actions in which individuals and groups are purposeful actors. In practice, consequences of actions are defined by the contextual conditions [43].

The following Figure 1 describes how the purposes and desires of individuals and groups in control of their own behavior are put into practice through the actions and interactions, and create the specific behaviors in a strategic IS change.

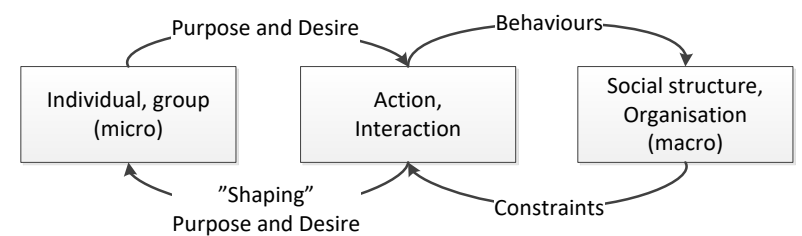

Figure 1. The interpretative process theory approach to a strategic IS change (applied from the conclusion of Cameron, Quinn 1988, p. 26)

As following an interpretative process theory approach in this study, in which the individuals contribute to practical reasoning and decision-making in actions $[15,44]$, the achievement of self- or otherregarding interests occur in interactions of individuals [14, p. 28]. By applying the theoretical assumption to this study social occurrences driven by the actions and interactions of individuals at micro-level can be seen meaningful for the strategic IS change [45]. 
Additionally, the interpretative process theory approach assumes that different entities involved in organizational events may change meanings over time why time-ordering of independent events is critical [46].

\section{Methodology and Research Setting}

The 15 in-depth interviews (with 16 interviewees, Table 1) were conducted from January 2013 to April 2013 in the leading country of the strategic IS change where the initial rollouts were in progress in five user organizations. The data collection was conducted inseparably with the data analysis (open, selective, and theoretical coding), and the concepts were allowed genuinely emerge from the data $[8,9,27]$. The Atlas.ti software tool was exploited to the open and selective coding phases, and analytical memos and diagrams were created in the separate documents.

Table 1. Interviewees and their roles in the strategic IS change process

\begin{tabular}{|c|c|}
\hline Organization & Interviewees (16) and their roles \\
\hline $\begin{array}{l}\text { Customer } \\
\text { (11 interview } \\
\text { sessions) }\end{array}$ & $\begin{array}{l}\text { Peter, CEO, Member of management } \\
\text { steering group; } \\
\text { John, CTO at the group level, } \\
\text { Member of management group; } \\
\text { Jacob, Former IT manager, Member } \\
\text { of management and IS product dev. } \\
\text { steering groups; } \\
\text { Philip, IT manager, Member of } \\
\text { management steering group; } \\
\text { David, Business area lead, Participant } \\
\text { in requirements workshop; } \\
\text { Aiden, Functional area lead, } \\
\text { Participant in requirements } \\
\text { workshop; } \\
\text { Matthew, Concept owner, Participant } \\
\text { in requirements workshop; } \\
\text { Mary, Controller, Participant in } \\
\text { requirements workshop; } \\
\text { Cecilia, User support and issue } \\
\text { management in IT team, New joiner } \\
\text { after the maternity leave; } \\
\text { Joseph, Technical specialist in IT } \\
\text { team; } \\
\text { Charlie, Lead in the user/initial } \\
\text { rollout organization, Participant in } \\
\text { requirements workshop; } \\
\text { William, User in the user/initial } \\
\text { rollout organization }\end{array}$ \\
\hline $\begin{array}{l}\text { Vendor } \\
(4 \text { interview } \\
\text { sessions })\end{array}$ & $\begin{array}{l}\text { Christian, CEO, Member of IS } \\
\text { product development and } \\
\text { management steering groups; } \\
\text { Daniel, Product development lead, } \\
\text { Member of IS product development } \\
\text { steering group; }\end{array}$ \\
\hline
\end{tabular}

\begin{tabular}{|l|l|}
\hline & $\begin{array}{l}\text { Sophia, Customer support, Member } \\
\text { of IS product development steering } \\
\text { group; } \\
\text { Anthony, Lead designer, Member of }\end{array}$ \\
$\begin{array}{l}\text { IS product development steering } \\
\text { group }\end{array}$ \\
\hline
\end{tabular}

After careful consideration of relations between the selective codes in the TC phase, the hypotheses of how two core categories 'Management of Change' and 'Tension and Uncertainty' are interrelated, were proposed. This led to the forming of the higher-level theme: the dynamic forming of social occurrences and paradoxes in a strategic IS change.

In this paper, after the discovery of the higher-level theme through the TC phase $[8,9,47]$, the selection of appropriate theoretical perspective was done for scaling up with the GT findings [48]. Throughout the GT process, the codes created are grounded on the data collected although the TCs are much more abstract than substantive codes created in open and selective coding phases [47]. A summary of theoretical integration, in which the synthesis of existing theoretical assumptions is applied to the own "theory" development, is presented in the chapter 5 .

\section{Case description}

The customer and vendor (Table 2) had collaborated for 15 years through the development of the current IS version in use. The customer became a significant investor to this strategic IS change initiative. The implementation was planned to run in the customer's 180 user organization globally in a long run. Already in a short run, the customer expected for the competitive advantage to their new service logic in their daily operations.

Table 2. Main participant organizations

\begin{tabular}{|l|l|}
\hline Customer & $\begin{array}{l}\text { Global service provider in retail business } \\
\text { (over 1000 employees) aims to renew the } \\
\text { business critical IS covering the business } \\
\text { critical functions such as customer service, } \\
\text { maintenance, inventory control, resource } \\
\text { planning, and finance in 180 user } \\
\text { organizations. Some customization needs in } \\
\text { all the modules. E.g. a critical business } \\
\text { process goes through all the functions. A } \\
\text { significant investor in this strategic IS } \\
\text { change. }\end{array}$ \\
\hline Vendor & $\begin{array}{l}\text { National IS provider in enterprise resource } \\
\text { planning business for accounting, retail and } \\
\text { chain of shops (over 80 employees in one } \\
\text { country and distant contractors abroad). } \\
\text { Module-based IS product development } \\
\text { supports an incremental approach in }\end{array}$ \\
\hline
\end{tabular}




\begin{tabular}{|l|l|}
\hline & $\begin{array}{l}\text { customer projects. Developing a new IS } \\
\text { product on a commercial platform in this } \\
\text { strategic IS change. }\end{array}$ \\
\hline
\end{tabular}

Because of the long IS partnership, informal/trustbased communication and coordination practices were well-established, especially, among the actors in the customer's IT unit and vendor's product development.

During the initial rollouts, tensions and uncertainties started dominating because the users were not able to run daily operations efficiently with the instable IS product version. The configuration possibilities on the new technical platform was also uncertain, and the customer-specific features were delayed. In general, it was very difficult to see any business benefits with the incomplete IS product version at this point. 'A cruel fact is that from the perspective of an IS investment the foreword for the IS project was in June 2010, and now we are turning to April 2013. Only few user organizations have been passed [initial rollout] now [with an incomplete system] including only customer service processes... without any "money back" [no return on investment] ... The entire work queue or requirements list is growing on the background. There are development requirements [waiting in the backlog] for the next four and half years... The biggest [most significant] view of this IS project is that the doing is extremely slow.' (John, CTO, Customer). For example, business-IS alignment related aspects, quality of the releases, and slow development cycles were the key issues in discussion of top managers in the customer. But still the actors in the customer's IT team and vendor's IS product development continued being committed in solving the issues, fixing the defects, and improving the testing procedures persistently.

The critical role changes at the mid-management (a leaving of the boundary spanner person [Jacob], and a joining of the new IT manager [Philip]) created the challenges to an integration of the macro and micro level views, and evaluation of the real status of the IS product development at the phase of the initial rollouts. Uncertainties about an ability to realize a business value to the customer with the selected technical platform raised the tensions further.

Unintended outcomes from the first releases led to the systemizing aims among the management. The new IT manager was assigned to the role for leading to the strategic IS change to more formal direction in which the emerging customer's requirements would be prioritized aligned with the IS product development. After the key role changes, the significant change to ways to collaborate was looked forward by many actors: 'Of course now after Jacob left, the modes of operating have changed, because he has been so strongly involved. And many things have been behind Jacob, in a way, in [our Country name] but also in [Country name 1] and [Country name 2]. So now we are both learning new models of operation regarding how we can take things forward in the future.' (Sophia, Customer support, Vendor). In this way, it was expected to succeed in the systemizing aims, and the enhancement of the collaboration.

\section{Construction of Higher-Level Theme}

TC phase aims to justify a set the hypotheses (propositions here) of how the relations between the selective codes are formed [27]. Theoretical "codes" are presented at the higher level of abstraction than selective codes "creating the good conditions to a theorizing" [47]. Through the TC phase in this study, seven social occurrences (Table 3, one example in Figure 2) were identified for explaining different co-evolvements of seven change management activities through the situated actions.

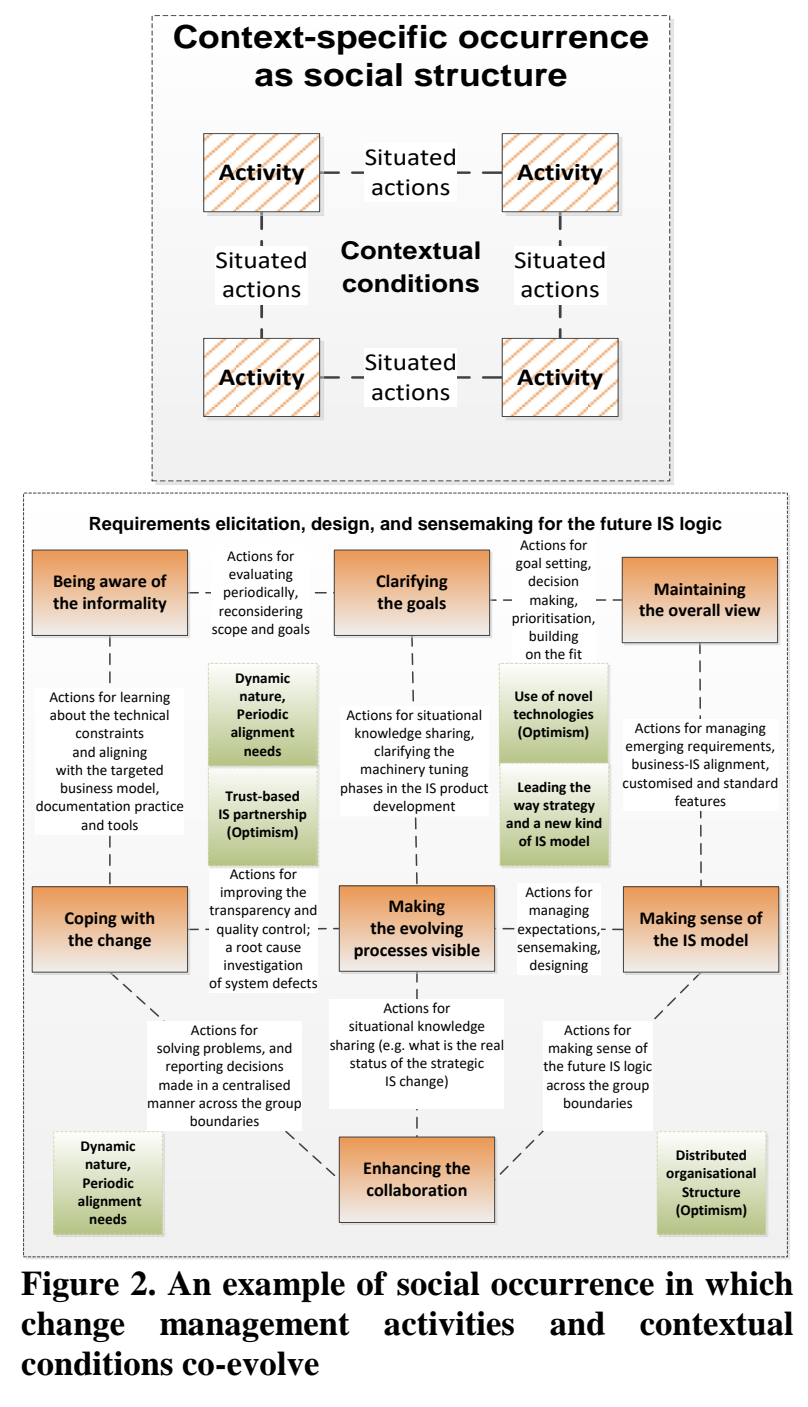

Page 5319 
Based on the discovery of higher-level theme in GT analysis, it is proposed, social occurrences emerge dynamically because of different choices in actions (e.g. learning about the technical constraints) and interactions of actors in the context (e.g. goal setting, prioritization, and decision-making). For example, the type of artefacts (IS requirements specification), means (communication manners via phone calls, emails and meetings), and social arrangements (requirements workshops at the early phase) applied to the requirements elicitation, design, and sensemaking for the future IS logic (Figure 2) naturally created different appearances of social occurrence in the context. Moreover, it was observable that some choices were constrained by the contextual condition such as the preexisting collaboration model in the code 'Excessive optimism'. For example, the informal and IT-driven collaboration model did not support the reactions to changing business requirements of the customers, and the long term aims to achieve the leading the way position in the customer's market enabled by the new IS product with the customizations.

When conceptualizing the relationships of change management activities with the aid of social occurrences (see Table 3, the first column), specific actions (artefacts, means, and social arrangements at the level of individual and group) become easily contradicting with the strategic IS change aims set at the organizational level for the long-term business benefits. In this way, it is easy to highlight the number of choices in actions that do not support the targeted change management structures. Examples of the specific choices in actions, and paradoxical situations identified in seven social occurrences are listed in the following Table 3 with the context data.

The contextual conditions emerged in the core category 'Tension and Uncertainty' (Table 3, the third column) are seen the contextual constraints to a forming of social occurrences during the strategic IS change. For example, with the limited number of participant actors, and too ambiguous and optimistic schedule for the strategic aims while the new technologies have been applied, the rationalization of the choices can be challenging. Hence, a set of choices in actions (artefacts, means, and social arrangements), organizational levels (individual, group, organization), purposes (strategic, managerial, practical), and timings

e.g. periodically) for the specific actions in situations can be restricted with the contextual conditions.

Moreover, the prevailing optimistic atmosphere in different organizational levels can create even an illusion of control (e.g. what is a real status of IS product development) which weaken an ability to make decision from the perspective of strategic IS change [49]. In the case studied, there was a significant amount of individual level freedom in actions because of the trustbased nature of IS partnership where informalities prevailed in knowledge sharing, designing, and managing of interrelated tasks. When a large set of choices in actions caused meaningful context-specific behaviors to social occurrences with unintended consequences of actions, the management of the strategic IS change became difficult. In the strategic IS change case analyzed, there was an excessive trust on the boundary spanning and knowledge integration $[11,12]$ of one individual actor. Jacob was able take care of situational knowledge sharing including the strategic IS change vision across the group boundaries. Excessive trust and optimism fed informalities through interpersonal relationships and individual level champion acting in the critical processes. Finally, the documentation (e.g. design artefacts) became insufficient to across organizational knowledge sharing in the distributed IS product development. The uncertainties related to the use of novel technology and development of the new IS model would have required for a periodic alignment over the contingencies including the comprehensive testing procedures and quality control for enabling the appropriate business-IS alignment, and reconsideration of a scope and goals.

As the following examples of seven social occurrences show (see Table 3), the micro-level actions (e.g. the requirements elicitation, design, and sensemaking for the future IS logic, Figure 2) occurred mostly at the individual level and early-phase why there were not possibilities to respond to the strategic IS change goals defined at the macro-level throughout the change process. For example, the critical actions for the business-IS alignment was insufficient after the early phase requirements workshops. The use of sufficient artefacts and social arrangements for making sense of the evolving business-IS model and future IS logic across the group boundaries were practically missing.

In general, in this kind of emergent and uncertain strategic IS change process, it is important to develop a contextual ambidexterity [39] for aligning the different views periodically, and adapting to the changing business needs efficiently in the IS product development. The context-specific ambidexterity areas emerged in social occurrences of this case were also presented in Table 3. For example, maintenance of both macro (strategic) and micro (practical) level views for the decision-making is necessary in this kind of strategic IS change organization where the steering groups (management and IT product development) are not aligned with their views because of the different agendas and time perspectives (long- vs. short-term goal setting). 
Table 3. The summary of social occurrences in which paradoxical situations were identified

\begin{tabular}{|c|c|c|}
\hline $\begin{array}{l}\text { Social occurrences / } \\
\text { Ambidexterities }\end{array}$ & Context data / Citations & $\begin{array}{l}\text { Contextual conditions and Paradoxical situations identified in } \\
\text { social occurrences }\end{array}$ \\
\hline $\begin{array}{l}\text { 1) The steering } \\
\text { group for a new IS } \\
\text { product } \\
\text { development } \\
\text { Lacking of the } \\
\text { business-IS alignment } \\
\text { acts throughout the } \\
\text { strategic IS change } \\
\text { process } \\
\text { Long- and Short- } \\
\text { term goal setting } \\
\text { Macro and Micro } \\
\text { views }\end{array}$ & $\begin{array}{l}\text { 'I was able to emphasize } \\
\text { the development orders } \\
\text { from the perspective of the } \\
\text { customer. I was leading the } \\
\text { opinions when there was a } \\
\text { decision point... based on } \\
\text { what are our expectations' } \\
\text { (Jacob, Former IT Manager, } \\
\text { Customer) } \\
\text { 'This fellow (Jacob) was } \\
\text { able to answer to everyone } \\
\text { on the spot. Now we have } \\
\text { not a person who knows } \\
\text { things... He also has the } \\
\text { end-to-end business } \\
\text { understanding.' (Philip, } \\
\text { New IT manager, } \\
\text { Customer). }\end{array}$ & $\begin{array}{l}\text { Asymmetrical knowledge structure in the critical decision making } \\
\text { (limited business view, boundary spanning and long-term goal } \\
\text { setting); } \\
\text { Short-term planning and goal setting at the micro level actions when } \\
\text { making decisions about the development tasks, resources, and } \\
\text { machinery tuning phases for the upcoming releases of the IS product } \\
\text { version. One IT manager, the voice of customer (long term), } \\
\text { participated in the steering group for a short period only; } \\
\text { Facilitation of the strategic IS change (macro view) with the set of } \\
\text { actions was limited in practical actions. Lacking of the customer's } \\
\text { strategic and long-term business view (after the leaving of Jacob) in } \\
\text { the new IS product development of the vendor (micro view). }\end{array}$ \\
\hline $\begin{array}{l}\text { 2) The requirements } \\
\text { elicitation, design, } \\
\text { and sensemaking for } \\
\text { the future IS logic } \\
\text { Lacking of the cross- } \\
\text { functionality and } \\
\text { evaluation of } \\
\text { requirements and } \\
\text { design periodically } \\
\text { Past and Future } \\
\text { Stable and Change }\end{array}$ & $\begin{array}{l}\text { 'This (change) is partly easy } \\
\text { and partly difficult. When } \\
\text { the customer has been using } \\
\text { the old version, and when } \\
\text { the specifications have been } \\
\text { fixed, many things have } \\
\text { been left unspecified. Of } \\
\text { course, it has been assumed, } \\
\text { by default, that they will be } \\
\text { the same as earlier' } \\
\text { (Anthony, Lead Designer, } \\
\text { Vendor). } \\
\text { 'If thinking of the group } \\
\text { who participated in the } \\
\text { requirements elicitation, of } \\
\text { course, it became passive } \\
\text { after the phase of } \\
\text { requirements workshops.' } \\
\text { (Jacob, Former IT Manager, } \\
\text { Customer). }\end{array}$ & $\begin{array}{l}\text { Clarification of design aims and goals occurred only informally with } \\
\text { the limited business view, the cross-functional group was not } \\
\text { involved in design after the early phase requirements workshops; } \\
\text { In the dynamic environment, the design should have been evaluated } \\
\text { by the cross-functional group of experts periodically for making sure } \\
\text { the parts of the design what are still relevant (stable) to the } \\
\text { environmental conditions, and what parts should be changed } \\
\text { accordingly. Unconnected business view (limited participation of } \\
\text { business representatives) challenged a periodic evaluation of the } \\
\text { design and IS product version against the evolving business-IS model; } \\
\text { The future IS logic was evaluated with the group of "champion" } \\
\text { actors at the initial rollouts when the first version was rolled out. } \\
\text { However, instabilities and fit-based concerns dominated in the first } \\
\text { IS product version. The key role changes increased uncertainties to the } \\
\text { requirements elicitation, design, and sensemaking; } \\
\text { The "old" (past) IS logic dominated the analysis and design during } \\
\text { the requirements workshops because of limited managerial facilitation } \\
\text { and technical competence to make sense of the future IS model. The } \\
\text { insufficient use of design artefacts to make sense of the future } \\
\text { business logic with the new technologies applied to the development. } \\
\text { The past IS product (currently in use) was a reference point. }\end{array}$ \\
\hline $\begin{array}{l}\text { 3) The management } \\
\text { of expectations, and } \\
\text { the different views } \\
\text { for the strategic IS } \\
\text { change } \\
\text { Lacking of the shared } \\
\text { view (road map) and } \\
\text { allowing informality } \\
\text { (excessive trust). } \\
\text { Macro and Micro } \\
\text { views }\end{array}$ & $\begin{array}{l}\text { '(Strategic and managerial } \\
\text { planning) was challenging } \\
\text { because the vendor was not } \\
\text { able to present a roadmap... } \\
\text { (Phasing) was done as } \\
\text { hand-to-mouth...' (Jacob, } \\
\text { former IT Manager, } \\
\text { Customer). } \\
\text { 'The management group } \\
\text { was very close to the global } \\
\text { management group ... when } \\
\text { information about the } \\
\text { strategic IS change was not } \\
\text { available, dissatisfaction }\end{array}$ & $\begin{array}{l}\text { Situational knowledge sharing occurred mostly at the early phase } \\
\text { with the aid of individual level boundary spanning. When the } \\
\text { former IT manager (Jacob) left, there was not link to the other IT } \\
\text { managers globally; } \\
\text { Balancing between the macro (the strategic IS change) and micro (the } \\
\text { development of the IS product) level views were managed } \\
\text { successfully with the aid of boundary spanning until the initial } \\
\text { rollouts; } \\
\text { A lack of road map for managing the expectations among the } \\
\text { stakeholders at the organizational level. In this case, the roadmap } \\
\text { would have been needed for consolidating both micro and macro } \\
\text { level actions to a shared view with the aid of which the real status and }\end{array}$ \\
\hline
\end{tabular}




\begin{tabular}{|c|c|c|}
\hline & $\begin{array}{l}\text { started prevailing among } \\
\text { the management in the other } \\
\text { countries... They have some } \\
\text { specific needs as well...' } \\
\text { (Matthew, Concept owner, } \\
\text { Customer). }\end{array}$ & $\begin{array}{l}\text { the realistic future steps in the strategic IS change process could have } \\
\text { been discussed: Creating a roadmap from the macro and micro level } \\
\text { views of the strategic IS change lacked of both strategic and } \\
\text { managerial efforts; }\end{array}$ \\
\hline $\begin{array}{l}\text { 4) The evaluation of } \\
\text { the IS product from } \\
\text { the perspective of } \\
\text { strategic IS change } \\
\text { Lacking of shared } \\
\text { practices and } \\
\text { evaluation of } \\
\text { requirements and } \\
\text { design periodically } \\
\text { Allowing the } \\
\text { excessive trust } \\
\text { (informality) } \\
\text { Long-and Short- } \\
\text { Term goal setting } \\
\text { Stability and Change }\end{array}$ & $\begin{array}{l}\text { 'Now we are doing a lot of } \\
\text { testing (on behalf of) [the } \\
\text { vendor]. We are identifying } \\
\text { the defects that they should } \\
\text { already have found (in their } \\
\text { testing environment)' (Peter, } \\
\text { CEO, Customer). } \\
\text { 'There are still lots of } \\
\text { customer wishes about what } \\
\text { they want. After the turn of } \\
\text { the year, during the } \\
\text { piloting, [they express] that } \\
\text { they want this and that, but } \\
\text { we've gone a bit backwards, } \\
\text { and the customer } \\
\text { understands it and agrees } \\
\text { that we should focus on } \\
\text { fixing these' (Sophia, } \\
\text { Customer support, Vendor). }\end{array}$ & $\begin{array}{l}\text { There was insufficient managerial support (e.g. spurring) and } \\
\text { practices (artefacts, means, and social arrangements) for supporting } \\
\text { the comprehensive evaluation of the IS product; } \\
\text { Especially, the possibilities to implement customer-specific features, } \\
\text { that would enable "Leading the way" strategy of the customer, should } \\
\text { have been evaluated critically with the aid of some prototypes, if the } \\
\text { production IS version was not completed; } \\
\text { The tight schedule and the overwhelming list of defects/issues } \\
\text { identified in the first IS version forced to short-term goal setting in } \\
\text { the IS product development. Long-term strategic business benefits } \\
\text { were difficult to evaluate with the incomplete IS product version in } \\
\text { the initial rollouts. } \\
\text { Slow evolvement of quality assurance (e.g. testing procedures) in the } \\
\text { IS product development made the stability of the IS product } \\
\text { challenging, especially, new requirements (changes) emerged } \\
\text { continuously when the first IS product version was used in the user } \\
\text { organizations. }\end{array}$ \\
\hline $\begin{array}{l}\text { 5) The issue } \\
\text { management in the } \\
\text { strategic IS change } \\
\text { and product } \\
\text { development } \\
\text { Lacking of centralized } \\
\text { tool for } \\
\text { comprehensive } \\
\text { recording of issues, } \\
\text { Inconsistencies in } \\
\text { documentation. } \\
\text { Centralized and } \\
\text { Distributed }\end{array}$ & $\begin{array}{l}\text { '[T]he volume is increasing } \\
\text { all the time. So, the models } \\
\text { of operation that we have } \\
\text { had with [the first piloting } \\
\text { organization] do not work } \\
\text { when we get many offices... } \\
\text { I have been exchanging } \\
\text { many emails with the end } \\
\text { users. This will not work } \\
\text { when there are several } \\
\text { offices, and you will drown } \\
\text { in the emails... On my part, } \\
\text { I have tried to deliver the } \\
\text { message that we should get } \\
\text { (customer requests, issues) } \\
\text { as much as possible through } \\
\text { our customer management, } \\
\text { so that it is more in control'. } \\
\text { (Sophia, Customer support, } \\
\text { Vendor). }\end{array}$ & $\begin{array}{l}\text { At the same time, when a lot of issues emerged, concerns about the } \\
\text { insufficient IS specifications were raised; } \\
\text { The customer's IT team and the vendor lead designer controlled and } \\
\text { pre-investigated the defects/issues. The customer extranet (a } \\
\text { centralized tool) did not support a comprehensive recording of issue } \\
\text { descriptions and knowledge sharing in the distributed IS product } \\
\text { development. } \\
\text { More managerial efforts were necessary for encouraging the actors in } \\
\text { the piloting stage and ensuring that the documentation is consistent } \\
\text { throughout the process (and at the organizational level) despite the } \\
\text { light design and quick issue solving needed within the tight timelines. } \\
\text { Additionally, managerial effort was required for improving the tools } \\
\text { that would support the right balance between centralization (tracking, } \\
\text { prioritization) and distribution (pre-investigation of issues). }\end{array}$ \\
\hline $\begin{array}{l}\text { 6) The enhancement } \\
\text { of the collaboration } \\
\text { in the informal and } \\
\text { trust-based IS } \\
\text { change culture } \\
\text { Informality } \\
\text { Control and Trust- } \\
\text { Based/Flexibility }\end{array}$ & $\begin{array}{l}\text { 'We do not want to go to } \\
\text { some rigid way of } \\
\text { developing software based } \\
\text { on the literature. Instead, } \\
\text { we are looking for agile } \\
\text { processes in which it is easy } \\
\text { to go back to the (design) } \\
\text { decisions made earlier' } \\
\text { (Philip, IT manager, } \\
\text { Customer). }\end{array}$ & $\begin{array}{l}\text { Adding control over the vendor's IS product development was } \\
\text { challenging in the trust-based IS change partnership, especially, } \\
\text { because of the key actor changes. Yet the new IT manager (Philip) } \\
\text { with the strategic purpose to systemize the IS change process had not } \\
\text { as much managerial power and knowledge and self-organized } \\
\text { practices were dominant. } \\
\text { Flexibility/self-organization was needed in practical actions. Better } \\
\text { control was required over the architectural aspects and long-term goal } \\
\text { setting for the strategic IS change; } \\
\text { Strategic decision-makers in the customer organization also had to be } \\
\text { able to participate in prioritization of the development. Acts to } \\
\text { increase control over the development occurred at the phase of } \\
\text { initial rollouts. }\end{array}$ \\
\hline
\end{tabular}




\begin{tabular}{|c|c|c|}
\hline $\begin{array}{l}\text { 7) The management } \\
\text { group for making } \\
\text { decisions about the } \\
\text { long-term goals and } \\
\text { schedule } \\
\text { Alignment and } \\
\text { adaptation } \\
\text { Long- and Short- } \\
\text { term goal setting } \\
\text { Macro and Micro } \\
\text { views }\end{array}$ & $\begin{array}{l}\text { 'Jacob got in touch with me } \\
\text { every week or even on daily } \\
\text { basis to tell me about } \\
\text { different kinds of things... I } \\
\text { can say that I was aware of } \\
\text { the problems or challenges } \\
\text { emerging (during the } \\
\text { strategic IS change)... I also } \\
\text { knew where (the progress) } \\
\text { they were going' (Peter, } \\
\text { CEO, Customer). }\end{array}$ & $\begin{array}{l}\text { Long term planning required for a realistic view of the strategic IS } \\
\text { change progress at the macro level. The critical business-IS alignment } \\
\text { and situational knowledge sharing with the aid of individual level } \\
\text { boundary spanner (Jacob). Jacob was able to inform the } \\
\text { management group about the micro level actions and the short-term } \\
\text { decisions in the IS product development until he was a part of the } \\
\text { strategic IS change; } \\
\text { By being active in both micro- and macro-level actions, Jacob was } \\
\text { capable to integrate knowledge from the different sub-processes to } \\
\text { in-form top managers about the practical progress of the strategic IS } \\
\text { change; } \\
\text { Arranged periodically but a realistic view of the overall strategic IS } \\
\text { change was present only at the early phase of the strategic IS change } \\
\text { with the aid of individual level boundary spanning. }\end{array}$ \\
\hline
\end{tabular}

Especially, if the IS product development aims at the competitive advantage with the strategic IS change, change and reframing abilities from the "old" (past) IS logic to new (future) logic are required for a differentiation, for example, by aligning the emerging business requirements continuously with the temporary stable IS model, architecture and design artefacts used for the IS product development.

Distributed organizational structures often allow the efficient operations in the groups in which the actors can be self-organized with their own short-term goals. However, some organizational level aims (e.g. prioritization of issues and requirements) should be defined and managed in a centralized manner for sharing the strategic IS change aims. Hence, the right approach to the strategic IS change initiatives is to find a balance among these ambidexterity areas prevailing in the strategic IS change.

\section{Conclusion and Future work}

In this study, the result from the GT analysis (after TC and theoretical integration phases) produced two propositions:

A) There are dynamic behaviors of change management activities in forming of new social occurrences in a context; and

B) The paradoxical situations emerge because of a set of choices in actions are not aligned with the aims in the strategic IS change.

The action-structure paradox [14] underlines the theoretical assumption related to the dualistic nature of structure shaped by actions over a course of time. Simultaneously the contextual conditions (e.g. preexisting social structures) set the constraints for the actions. The paradoxical situations arose because the specific choices of actions did not support the targeted management structure for the strategic IS change. This second proposition gave reason to incorporate ideas from the ambidexterity literature in the theoretical integration. For example, a dynamic capability (as conceptualized in ambidexterity thinking) is required for a response to paradoxes by simultaneously aligning and adapting in strategic IS change organization when tensions and uncertainties prevail $[14,29,35,39]$.

As a novel perspective on strategic IS change, this study aims at contributing to the review of Besson and Rowe [22] in which the different dimensions of organizational inertias for strategic IS change have been outlined. In this study, the antecedent structures prevailing in strategic IS change (e.g. the trust-based IS partnership, the prevailing optimistic atmosphere and IT-driven collaboration model, and the distributed organizational structure) restricted the change toward an adaptive mode of operating with specific contextual ambidexterity [39]. Hence, some sources of tensions and uncertainties explained the socio-cognitive aspects of organizational inertia such as an illusion of control because of excessive optimism in the critical decision making $[49,50]$. The informalities and inconsistencies in practices, the boundary spanning behavior (which was visible in one individual actor, Jacob, Former IT manager), and the limited participation of the business representatives after the requirements workshops enhanced the individual level freedom and low control of practical realizations of the strategic IS change aims in the micro-level actions.

As a managerial contribution, it can be concluded that managers and decision-makers can better deal with tensions and uncertainties arising in strategic IS change if they develop contextual ambidexterity, i.e. "the behavioral capacity to simultaneously demonstrate alignment and adaptability across an entire [strategic IS change organization]" [51]. In this vein, there are both research and managerial opportunities to identify and explore the context-specific ambidexterity areas in strategic IS change initiatives [28]. 
When analyzed further, the tensions and uncertainties identified as contextual conditions of strategic IS change within change management activities can be seen as triggers to both virtuous and vicious cycles in strategic IS change management. In this study, particularly, after the departure of the boundary spanner competence (Jacob, Former IT manager), the vicious cycles started dominating, and caused many negative consequences of actions in relation to the targeted IS change. The question of how to develop more contextual ambidexterity as a response to contextual conditions, which can restrict the strategic IS change process, would be an interesting future research avenue that could build upon the analysis presented here. A further development and exploration of the higher-level theme discovered with the theoretical propositions in this study would also provide additional avenues for theoretical contribution.

\section{Acknowledgement}

This study was funded by the Academy of Finland (grant numbers 259454 and 259831).

\section{References}

[1] G. Piccoli, B. Ives, Review: IT-Dependent Strategic Initiatives and Sustained Competitive Advantage: A Review and Synthesis of the Literature, MIS Quarterly. 29 (2005) 747-776.

[2] J.W. Ross, C.M. Beath, D.L. Goodhue, Develop longterm competitiveness through IT assets, Sloan Manage. Rev. 38 (1996) 31.

[3] M. Jarke, P. Loucopoulos, K. Lyytinen, J. Mylopoulos, W. Robinson, The brave new world of design requirements, Inf Syst. 36 (2011) 992-1008.

[4] M. Bensaou, N. Venkatraman, Inter-organizational relationships and information technology: A conceptual synthesis and a research framework, European Journal of Information Systems. 5 (1996) 84-91.

[5] L.J. Bourgeois, Strategic goals, perceived uncertainty, and economic performance in volatile environments, Academy of management journal. 28 (1985) 548-573. [6] W.K. Smith, Dynamic decision making: A model of senior leaders managing strategic paradoxes, Academy of Management Journal. 57 (2014) 1592-1623.

[7] M. Erez, S. Jarvenpaa, M. Lewis, W. Smith, P. Tracey, Paradox, tensions and dualities of innovation and Change, (2013).

[8] B.G. Glaser, Doing Grounded Theory: Issues and Discussions, Sociology Press, 1998.

[9] B.G. Glaser, Emergence Vs Forcing: Basics of Grounded Theory Analysis, Sociology Press, 1992.

[10] H. Tsoukas, R. Chia, On organizational becoming: Rethinking organizational change, Organization Science. 13 (2002) 567-582.

[11] N. Levina, E. Vaast, The emergence of boundary spanning competence in practice: implications for implementation and use of information systems, MIS quarterly. (2005) 335-363.

[12] A. Fisk, N. Berente, K. Lyytinen, Boundary spanning competencies and information system development project success, ICIS 2010 Proceedings. (2010).

[13] S.T. Koeszegi, Trust-building strategies in interorganizational negotiations, J. Manage. Psychol. 19 (2004) 640-660.

[14] K.S. Cameron, R.E. Quinn, Organizational Paradox and Transformation. Ballinger Publishing Co/Harper \& Row Publishers, 1988.

[15] J.G. March, Bounded rationality, ambiguity, and the engineering of choice, The Bell Journal of Economics. (1978) 587-608.

[16] H. Akkermans, K. van Helden, Vicious and virtuous cycles in ERP implementation: a case study of interrelations between critical success factors, European journal of information systems. 11 (2002) 35-46.

[17] J.W. Forrester, The beginning of system dynamics, McKinsey Quarterly. (1995) 4-17.

[18] W.K. Smith, M.W. Lewis, Toward a theory of paradox: A dynamic equilibrium model of organizing, Academy of Management Review. 36 (2011) 381-403.

[19] C. Sundaramurthy, M. Lewis, Control and collaboration: Paradoxes of governance, Academy of Management Review. 28 (2003) 397-415.

[20] K.E. Weick, R.E. Quinn, Organizational change and development, Annu. Rev. Psychol. 50 (1999) 361-386.

[21] J. Pfeffer, New Directions for Organization Theory:

Problems and Prospects, Oxford University Press New York, 1997.

[22] P. Besson, F. Rowe, Strategizing information systemsenabled organizational transformation: A transdisciplinary review and new directions, The Journal of Strategic Information Systems. 21 (2012) 103-124.

[23] L. McLeod, B. Doolin, Information systems development as situated socio-technical change: a process approach, European Journal of Information Systems. 21 (2012) 176-191.

[24] M.W. Lewis, Exploring paradox: Toward a more comprehensive guide, Academy of Management Review. 25 (2000) 760-776.

[25] M.S. Poole, Van de Ven, Andrew H, Using paradox to build management and organization theories, Academy of management review. 14 (1989) 562-578.

[26] C. Urquhart, W. Fernández, Using grounded theory method in information systems: the researcher as blank slate and other myths, J. Inf. Technol. 28 (2013) 224-236.

[27] B.G. Glaser, Theoretical Sensitivity: Advances in the Methodology of Grounded Theory, Sociology Press Mill Valley, CA, 1978.

[28] R.W. Gregory, M. Keil, J. Muntermann, M. Mähring, Paradoxes and the Nature of Ambidexterity in IT

Transformation Programs, Information Systems Research. 26 (2015) 57-80.

[29] M.L. Tushman, C.A. O’Reilly III, Managing

evolutionary and revolutionary change, Calif. Manage. Rev. 38 (1996) 8-28.

[30] M. Tushman, D. Nadler, Organizing for innovation, Calif. Manage. Rev. 28 (1986) 74-92. 
[31] C.A. O Reilly, M.L. Tushman, The ambidextrous organization, Harv. Bus. Rev. 82 (2004) 74-83.

[32] C.C. Markides, Business model innovation: what can the ambidexterity literature teach us? The Academy of Management Perspectives. 27 (2013) 313-323.

[33] C. Andriopoulos, M.W. Lewis, Exploitation-exploration tensions and organizational ambidexterity: Managing paradoxes of innovation, Organization Science. 20 (2009) 696-717.

[34] S. Raisch, J. Birkinshaw, G. Probst, M.L. Tushman, Organizational ambidexterity: Balancing exploitation and exploration for sustained performance, Organization science. 20 (2009) 685-695.

[35] C.A. O'Reilly, M.L. Tushman, Ambidexterity as a dynamic capability: Resolving the innovator's dilemma, Research in organizational behavior. 28 (2008) 185-206. [36] S. Raisch, J. Birkinshaw, Organizational ambidexterity: Antecedents, outcomes, and moderators, Journal of management. (2008).

[37] M.L. Tushman, C.A. O’Reilly III, Ambidextrous organizations: Managing evolutionary and revolutionary change, Managing innovation and change. (2006) 170. [38] P. Jarzabkowski, J. Lê, Van de Ven, Andrew H, Responding to competing strategic demands: How organizing, belonging, and performing paradoxes coevolve, Strategic Organization. (2013) 1476127013481016.

[39] N.P. Napier, L. Mathiassen, D. Robey, Building contextual ambidexterity in a software company to improve firm-level coordination, European Journal of Information Systems. 20 (2011) 674-690.

[40] A. Karpovsky, R.D. Galliers, Aligning in practice: from current cases to a new agenda, J. Inf. Technol. 30 (2015) 136-160.
[41] K. Lyytinen, M. Newman, A tale of two coalitionsmarginalising the users while successfully implementing an enterprise resource planning system, Information Systems Journal. (2014).

[42] T. Parsons, The Structure of Social Action, Free Press New York, 1949.

[43] A.M. Pettigrew, Context and action in the transformation of the firm, Journal of management studies. 24 (1987) 649-670.

[44] J.G. March, H.A. Simon, Organizations. (1958).

[45] J. Peppard, R.D. Galliers, A. Thorogood, Information systems strategy as practice: Micro strategy and strategizing for IS. J.Strategic Inf.Sys. 23 (2014) 1-10.

[46] Van de Ven, Andrew H, M.S. Poole, Alternative approaches for studying organizational change, Organ. Stud. 26 (2005) 1377-1404.

[47] B.G. Glaser, The Grounded Theory Perspective III: Theoretical Coding, Sociology Press, 2005.

[48] C. Urquhart, Grounded Theory for Qualitative Research: A Practical Guide, Sage, 2012.

[49] V.L. Mitchell, Knowledge integration and information technology project performance, Mis Quarterly. (2006) 919939.

[50] D. Kahneman, D. Lovallo, O. Sibony, Before you make that big decision, Harv. Bus. Rev. 89 (2011) 50-60.

[51] C.B. Gibson, J. Birkinshaw, The antecedents, consequences, and mediating role of organizational ambidexterity, Academy of management Journal. 47 (2004) 209-226. 